OPEN ACCESS

Edited by:

Susu M. Zughaier,

Qatar University, Qatar

Reviewed by:

Ran Reshef,

Columbia University, United States

Antonio Pierini,

University of Perugia, Italy

${ }^{*}$ Correspondence:

Heiko Bruns

heiko.bruns@uk-erlangen.de

Specialty section:

This article was submitted to

Microbial Immunology,

a section of the journal

Frontiers in Immunology

Received: 08 July 2019

Accepted: 18 October 2019

Published: 05 November 2019

Citation:

Flamann C, Peter K, Kreutz M and Bruns H (2019) Regulation of the Immune Balance During Allogeneic

Hematopoietic Stem Cell

Transplantation by Vitamin $D$.

Front. Immunol. 10:2586.

doi: 10.3389/fimmu.2019.02586

\section{Regulation of the Immune Balance During Allogeneic Hematopoietic Stem Cell Transplantation by Vitamin D}

\author{
Cindy Flamann ${ }^{1}$, Katrin Peter ${ }^{2}$, Marina Kreutz ${ }^{2}$ and Heiko Bruns ${ }^{1 *}$ \\ ${ }^{1}$ Department of Internal Medicine 5, Hematology/Oncology, Friedrich Alexander University Erlangen-Nuremberg, Erlangen, \\ Germany, ${ }^{2}$ Department of Internal Medicine III - Hematology and Internal Oncology, University Hospital of Regensburg, \\ Regensburg, Germany
}

One of the most promising therapeutic approaches for numerous hematological malignancies represents the allogeneic hematopoietic stem cell transplantation (allo-HSCT). One major complication is the development of the life-threatening graft-vs.-host disease (GvHD) which limits beneficial effects of graft-vs.-leukemia (GvL) responses during allo-HSCT. Strengthening GVL effects without induction of severe GvHD is essential to decrease the relapse rate after allo-HSCT. An interesting player in this context is vitamin $D_{3}$ since it has modulatory capacity in both preventing GVHD and boosting GvL responses. Current studies claim that vitamin $D_{3}$ induces an immunosuppressive environment by dendritic cell (DC)-dependent generation of regulatory $T$ cells (Tregs). Since vitamin $\mathrm{D}_{3}$ is known to support the antimicrobial defense by re-establishing the physical barrier as well as releasing defensins and antimicrobial peptides, it might also improve graft-vs.-infection (Gvl) effects in patients. Beyond that, alloreactive $T$ cells might be attenuated by vitamin $\mathrm{D}_{3}$-mediated inhibition of proliferation and activation. Despite the inhibitory effects of vitamin $D_{3}$ on $T$ cells, anti-tumor responses of GvL might be reinforced by vitamin $D_{3}$-triggered phagocytic activity and antibody-based immunotherapy. Therefore, vitamin $\mathrm{D}_{3}$ treatment does not only lead to a shift from a pro-inflammatory toward a tolerogenic state but also promotes tumoricidal activity of immune cells. In this review we focus on vitamin $D_{3}$ and its immunomodulatory effects by enhancing anti-tumor activity while alleviating harmful allogeneic responses in order to restore the immune balance.

Keywords: vitamin D, GvH, GvL, immune balance, macrophages, T cells, infection

\section{INTRODUCTION}

The most promising curative therapeutic strategy for a broad spectrum of hematological malignancies remains the allogeneic hematopoietic stem cell transplantation (allo-HSCT) (1). Its efficacy is mainly mediated by alloreactive donor-derived immune cells eliminating malignant host cells, a process known as graft-vs.-leukemia (GvL) effect (2). However, infused donor cells can also attack healthy host tissues due to histocompatibility mismatches, which leads to graft-vs.-host disease (GvHD). This life-threatening complication limits the beneficial effects mediated by GvL. Restoring the host's immune balance during and after transplantation is one of the major 
challenging obstacles in clinical research (3). Alleviating GvHD responses while boosting anti-leukemia activities could be the key to successful treatment in allo-HSCT. Since both processes underlie more or less the same $\mathrm{T}$ cell activity, it is very demanding to dissect GvHD from GvL effects (4). The current standard treatment consists mainly of corticosteroids and calcineurin inhibitors such as cyclosporine and tacrolimus (5). Since these immunosuppressive drugs attenuate T-cellmediated inflammation (6) and the allo-stimulatory capacity of DCs (7), they lead to alleviation of GvHD symptoms. However, these immunosuppressive mechanisms might reduce GvL effects as well. Recent studies have established promising strategies for strengthening GvL responses without exacerbating GvHD. Infusion of donor lymphocytes, CAR-T cells and checkpoint inhibitors have gained pivotal interest in clinical studies over the past years (8). However, none of these therapeutic approaches target both GvHD and GvL.

Though vitamin $\mathrm{D}_{3}$ has been discovered as an important regulator of calcium homeostasis in the early Twentieth century, its putative immunoregulatory role remained undiscovered until recently (9). Contrary to initial assumptions that vitamin $D_{3}$ is mainly produced in kidney and liver, vitamin $\mathrm{D}_{3}$ receptor (VDR) and vitamin $D_{3}$ metabolizing enzymes are also expressed in various types of immune cells (10-12). The novel role of vitamin $\mathrm{D}_{3}$ in regulating effector functions of human macrophages is closely linked to the expression of the vitamin D-1-hydroxylase CYP27B1. The precursor form of vitamin $\mathrm{D}_{3}$ is produced in the epidermis upon ultraviolet $B$ (UVB) irradiation or obtained from dietary intake (13). Vitamin $\mathrm{D}_{3}$-binding protein (VDBP) binds pre-vitamin $\mathrm{D}_{3}$ and is responsible for its transport into the liver. Upon entering the cell, CYP27B1 catalyzes the conversion of 25hydroxy-vitamin $\mathrm{D}_{3}\left(25(\mathrm{OH}) \mathrm{D}_{3}\right)$ into its bioactive form 1,25 dihydroxy-vitamin $\mathrm{D}_{3}\left(1,25(\mathrm{OH})_{2} \mathrm{D}_{3}\right.$, calcitriol) (14). Levels of $1,25(\mathrm{OH})_{2} \mathrm{D}_{3}$ are regulated by the inactivating $1,25(\mathrm{OH})_{2} \mathrm{D}_{3} 24$ hydroxylase (CYP24A1). 1,25(OH) ${ }_{2} \mathrm{D}_{3}$ binds intracellularly to VDR and induces as a transcription factor the expression of a broad variety of target genes which contain vitamin $\mathrm{D}_{3}$ response elements (VDRE) within their promoters (15) (Figure 1).

Since vitamin $D_{3}$ is well-known for exerting both antitumoricidal and anti-inflammatory functions, it might be an attractive target for preservation of the immune balance in patients undergoing allo-HSCT (16). In this review, we seek to elucidate mechanisms by which vitamin $\mathrm{D}_{3}$ might act as potential immune regulator in GvL as well as GvHD while highlighting its effects on both innate and adaptive immune system.

\section{VITAMIN $D_{3}$ AND GvHD}

At the beginning of the Twenty-first century, vitamin $\mathrm{D}_{3}$ has gained more attention in the field of allo-HSCT. Given that vitamin $\mathrm{D}_{3}$ exerts "non-classical" actions besides sustaining bone metabolism and calcium homeostasis, paved the way for pioneering studies which proved that vitamin $\mathrm{D}_{3}$ deficiency correlates directly with immune diseases such as multiple sclerosis (MS) (17), systemic lupus erythematosus (18), inflammatory bowel disease (IBD) (19), rheumatoid arthritis
(20), and autoimmune thyroid disease (21). Vitamin $\mathrm{D}_{3}$ supplementation has been shown to reduce severity and incidence of such diseases not only in animal models but also in clinical studies (22). Based on studies which show that application of several vitamin $\mathrm{D}_{3}$ analogs has been effective in some solid organ transplantations (23-25), Pakkala and colleagues successfully achieved prevention of GvHD symptoms in a rat transplantation model by a $1,25(\mathrm{OH})_{2} \mathrm{D}_{3}$ analog (MC1288) (26). Further investigations proved that certain VDR polymorphisms are associated with higher risk of severe GvHD (27-29). Since patients receiving HSCT are malnourished, less exposed to sunlight and have an altered vitamin $\mathrm{D}_{3}$ metabolism due to medications and impaired organ function, they are predestined for vitamin $\mathrm{D}_{3}$ deficiency (30). In fact, Kreutz et al. demonstrated that conversion of $25(\mathrm{OH}) \mathrm{D}_{3}$ into $1,25(\mathrm{OH})_{2} \mathrm{D}_{3}$ is impaired in GvHD patients and that $25(\mathrm{OH}) \mathrm{D}_{3}$ serum levels were lower in grade III-IV than in grade I-II GvHD patients (31). The high prevalence of low vitamin D3 levels in patients undergoing HSCT is reported in other studies as well and might also be associated with a higher incidence of GvHD (32-34). These findings suggest a pivotal protective role of vitamin $\mathrm{D}_{3}$ in GvHD pathogenesis. Recently, Chen and Mayne reviewed the immunomodulatory effects of vitamin $\mathrm{A}$ and $\mathrm{D}$ in the context of GvHD (35). In the following, vitamin $\mathrm{D}_{3}$ will be analyzed briefly as an important modulator of both innate and adaptive immune system.

\section{Molecular Actions of Vitamin $D_{3}$ in the Innate Immune System of GvHD Patients Antimicrobial Activities}

Although the precise mechanisms of vitamin $\mathrm{D}_{3}$ remained unclear for a long time, patients infected with Mycobacterium tuberculosis $(M t b)$ have been treated with UVB irradation and cod liver oil in the pre-antibiotic era $(36,37)$. In 1980 , Rook and colleagues could evidence that growth of $M t b$ was impeded in vitro by $1,25(\mathrm{OH})_{2} \mathrm{D}_{3}$ in human monocytes and macrophages $(38,39)$. Since then, it became increasingly clear that vitamin $\mathrm{D}_{3}$ exerts anti-microbial effects (40). Subsequent studies demonstrated that $1,25(\mathrm{OH})_{2} \mathrm{D}_{3}$ leads to release of anti-microbial peptides such as LL-37 and $\beta$-defensin (4143). LL-37 is the cleavage product of human cathelicidin antimicrobial peptide (hCAP18, CAMP) and is known for its antibacterial function by inducing bacterial lysis and death (44). Upon infection, lung epithelial cells locally produce $1,25(\mathrm{OH})_{2} \mathrm{D}_{3}$ which in turn enhances LL-37 expression (45). Cathelicidin-deficient mice have been shown to be more susceptible to infections with Streptococcus, Pseudomonas, and E. coli (46). Cathelicidin does not only increase phagocytic activity of macrophages (47) but also promotes reactive oxygen species (ROS) production $(48,49)$, leading to direct antimicrobial effects. Moreover, cathelicidin triggers autophagy and reactivates phagolysosomal fusion in macrophages, which enhances degradation of intracellular pathogens such as $M t b$, Salmonella, and Coxiella (14, 50). Even viral infections with influenza A (51) or fungal infections with Candida albicans (52) in mice are reduced by cathelicidin. Accumulating data 


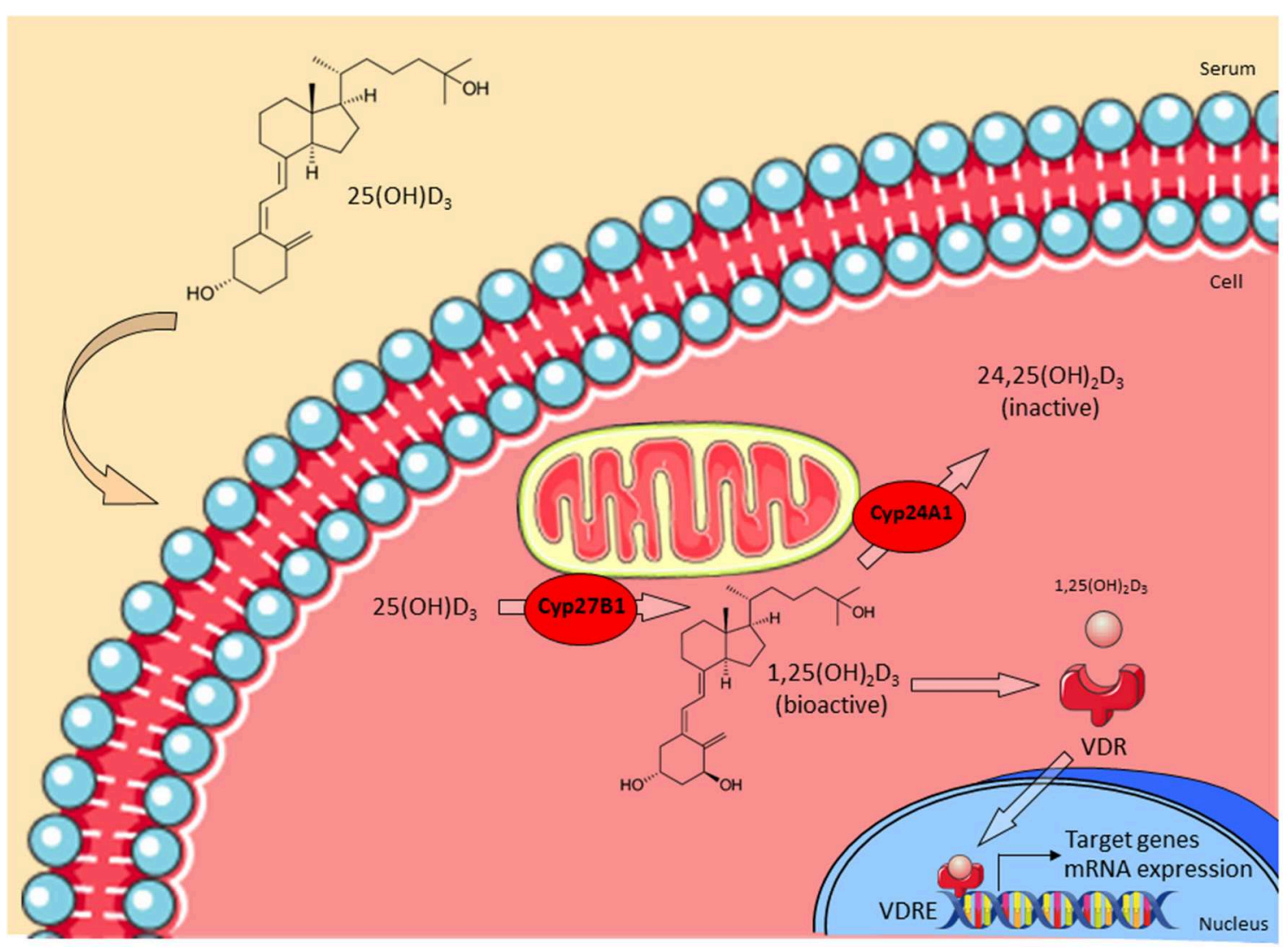

FIGURE 1 | Vitamin $D_{3}$ metabolism. The precursor form of vitamin $D_{3} 25(\mathrm{OH}) \mathrm{D}_{3}$ enters the cell and is then converted into the bioactive form $1,25(\mathrm{OH})_{2} \mathrm{D}_{3}$ by CYP27B1. CYP24A1 regulates levels of $1,25(\mathrm{OH})_{2} \mathrm{D}_{3}$ by converting it into the inactive $24,25(\mathrm{OH})_{2} \mathrm{D}_{3}$. Active $1,25(\mathrm{OH})_{2} \mathrm{D}_{3}$ binds to the vitamin $\mathrm{D}_{3}$ receptor $(\mathrm{VDR})$ in the cytoplasm and this complex translocates into the nucleus. Finally, VDR binds to appropriate vitamin D response elements (VDRE) and triggers transcription of target genes (e.g., LL-37). Adapted from Bruns and Stenger (14).

have revealed that the intestinal barrier is supported by vitamin $\mathrm{D}_{3}$-dependent upregulation of tight junction proteins (53, 54), which is a fundamental requirement for efficient defense against pathogens. The loss of intestinal barrier function is also considered to be a driving factor for GvHD development (55). Thus, vitamin $\mathrm{D}_{3}$-dependent release of cathelicidin and the protection of epithelial barriers might improve graft- vs.infection (GVI) effects in allo-HSCT patients.

Recent studies have now discovered a novel role of LL-37 in cancer (56) and inflammatory diseases (57). Strikingly, LL-37 does not only possess anti-microbial but also anti-inflammatory features, since it has been shown to inhibit the release of pro-inflammatory mediators such as TNF- $\alpha$, IL- 6 , and IL- 8 by neutrophils (48). Additionally, cathelicidin reduces mortality in mice infected with $P$. aeruginosa by neutralizing endotoxinmediated inflammation (58).

Hence, vitamin $\mathrm{D}_{3}$-triggered activity of cathelicidin links antimicrobial and anti-inflammatory effects in the innate immune system. Since GvHD patients have an increased risk for severe infections due to immunosuppressive drugs (59), vitamin $\mathrm{D}_{3}$ mediated enhancement of antimicrobial defense mechanisms might reduce co-morbidity by infectious diseases. Therefore, it is conceivable that vitamin $\mathrm{D}_{3}$ might play an important and yet unrecognized role in GVI.

\section{Anti-inflammatory Effects}

As already mentioned, vitamin $\mathrm{D}_{3}$ elicits not only antimicrobial but also anti-inflammatory responses. Even though vitamin $\mathrm{D}_{3}$ enhances the maturation of human macrophages and their function as phagocytes (60), their capacity of antigen presentation and consequently also the priming of $\mathrm{T}$ cells is limited due to reduction of MHC-II expression $(30,61)$. Instead, $1,25(\mathrm{OH})_{2} \mathrm{D}_{3}$ polarizes macrophages toward an antiinflammatory M2 subtype, which restrains colitis in mice (62). In humans and mice, vitamin $\mathrm{D}_{3}$ generates a tolerogenic phenotype and alters the cytokine and chemokine profile of mature DCs (mDCs) in vivo and in vitro, which are inhibited in differentiation, maturation and proliferation (63-65). In mixed lymphocyte reactions, proliferation of $\mathrm{T}$ cells, co-cultured with these $1,25(\mathrm{OH})_{2} \mathrm{D}_{3}$-induced tolerogenic DCs, was indirectly inhibited. Apart from preventing DCs to home into the lymph node by reducing CCR7-expression, vitamin $\mathrm{D}_{3}$ also decreases expression of the co-stimulatory molecules CD40, CD80 and 
CD86 and secretion of cytokines such as IL-6, IL-12, and TNF$\alpha$ (66). Recently, Saul and colleagues revealed that CD31 is increasingly expressed on DCs, leading to impairment of cellcell contact, which is essential for T cell priming (67). Moreover, secretion of immunosuppressive IL-10 is enhanced while IL-12 secretion by DCs is impaired, which leads to a weaker T helper Th1 - and Th17- cell immune response (68). As a result, activation and differentiation of alloreactive $\mathrm{CD}^{+} \mathrm{T}$ cells is reduced in vitro (65). Furthermore, vitamin $\mathrm{D}_{3}$-treated $\mathrm{DCs}$ increase the frequency of suppressive $\mathrm{CD} 4^{+} \mathrm{CD} 25^{+} \mathrm{FoxP}_{3}^{+}$regulatory $\mathrm{T}$ cells (Treg) (69), which fosters peripheral tolerance to allografts (70). One study indicated that vitamin $\mathrm{D}_{3}$-mediated increase of $\mathrm{CD}^{+}{ }^{+} \mathrm{FoxP}_{3}^{+} \mathrm{Nrp}-1^{+}$cells ameliorates collagen-induced arthritis (71). Recently, $\mathrm{Xu}$ and colleagues established engineered DCs to de novo produce calcitriol in order to generate more guthoming Tregs for efficient mitigation of intestinal inflammation (72). These results proved that $1,25(\mathrm{OH})_{2} \mathrm{D}_{3}$-induced tolerogenic DCs modulate $\mathrm{T}$ cells toward a regulatory and anti-inflammatory immune response in vivo and ameliorate acute GvHD (aGvHD) in mice $(64,73)$. Coussens and colleagues suggest that vitamin $\mathrm{D}_{3}$ supplementation in tuberculosis patients helps to restrict inflammatory responses by reducing circulating concentrations of chemokines such as CXCL9, CXCL10, and MMP-9 $(74,75)$. Additionally, upregulation of chemokine receptor CXCR3 fosters DC migration to inflammation spots (69). In vitro studies showed that Janus kinase/signal transducers and activators of transcription (JAK/STAT) signaling and inflammatory cytokines, such as IFN- $\gamma$, TNF- $\alpha$, and Flt-3L, are significantly reduced in NK-cells upon vitamin $\mathrm{D}_{3}$-treatment or its analog seocalcitol (EB1089) (76). Interestingly, JAK1/2 have already been identified as potential therapeutic targets in GvHD since it was shown to reduce GvHD in mice while GvT could be preserved (77). Clinical trials verified that the JAK1/2 inhibitor Jakafi ${ }^{\circledR}$ (Ruxolitinib) reduces efficiently steroid-refractory $\operatorname{GvHD}(78,79)$ and has recently been approved by the U.S. Food and Drug Administration (FDA).

Altogether, vitamin $\mathrm{D}_{3}$ modifies the innate immune system by exerting not only anti-microbial but also anti-inflammatory functions. Since GvHD patients often show co-morbidity of fungal, viral and bacterial infections $(80,81)$, increased infection rate as well as exaggerated inflammation are key issues needed to be combatted in this disease. Since persistence of APCs despite the conditioning regimen is the major cause of generation of alloreactive lymphocyte, manipulation of the innate immune system toward tolerogenic host-DCs by vitamin $\mathrm{D}_{3}$ in order to reduce their allo-stimulatory potential might help to prevent GvHD (82).

\section{Effects of Vitamin $D_{3}$ on the Adaptive Immune System}

Apart from the above discussed indirect effects on $\mathrm{T}$ cells by vitamin $\mathrm{D}_{3}$-dependent modulation of innate immune cells, the hormone has also direct impacts on the adaptive immune system since $\mathrm{T}$ cells are known to express VDR, which enables them to respond to $1,25(\mathrm{OH})_{2} \mathrm{D}_{3}$ (83). Although the VDR appeared to be upregulated in activated alloreactive $\mathrm{T}$ cells indicating a role of vitamin $\mathrm{D}_{3}$ in $\mathrm{T}$ cell activation (30), studies proved that $1,25(\mathrm{OH})_{2} \mathrm{D}_{3}$ directly inhibits proliferation and IL2 production of $\mathrm{CD}^{+} \mathrm{T}$ cells $(84,85)$. Similar to its effect on APCs, $1,25(\mathrm{OH})_{2} \mathrm{D}_{3}$ reduces expression of homing receptors such as CCR10 as well as secretion of IFN- $\gamma$ and IL-10 by $\mathrm{T}$ cells (86). Especially Th1 cell proliferation is inhibited via the JAK/STAT signaling pathway (87), while Th2 cells are increased directly $(88,89)$. Therefore, vitamin $\mathrm{D}_{3}$ alters the $\mathrm{T}$ cell immunity by transforming Th1- and Th17-responses toward an anti-inflammatory Th2-activity. This mechanism is even amplified since expression of CYP27B1 is also enhanced in activated lymphocytes (30). $\mathrm{CD}^{+} \mathrm{T}$ cells are inhibited in proliferation in vitro and in vivo by vitamin $\mathrm{D}_{3}$ (90). It is documented that vitamin $\mathrm{D}_{3}$ inhibits pro-inflammatory $\mathrm{T}$ cells in IBD patients (91). Since IBD pathogenesis is driven by loss of intestinal barrier function, clinical manifestations of IBD resemble GvHD symptoms in the gastrointestinal tract (55). Such parallels suggest that vitamin $\mathrm{D}_{3}$ might achieve similar effects in allo-HSCT. However, $1,25(\mathrm{OH})_{2} \mathrm{D}_{3}$ does not only affect $\mathrm{T}$ cells but also modulates differentiation and antibody-production of B cells (92). In addition, it induces apoptosis and cell cycle arrest of proliferating $B$ cells resulting in impaired plasma cell differentiation and less autoantibody expression (93).

Altogether, vitamin $\mathrm{D}_{3}$ has an overall anti-microbial and antiinflammatory effect on both innate and adaptive immune system. Therefore, vitamin $\mathrm{D}_{3}$ could be a potent supplementary agent in GvHD patients which might improve the patient's life quality by decreasing infectious- and inflammation-mediated co-morbidity.

\section{POTENTIAL GvL-EFFECTS MEDIATED BY VITAMIN $D_{3}$}

As mentioned earlier, it is pivotal to preserve the immune balance by avoiding alloreactivity of donor $\mathrm{T}$ cells against healthy tissue while still maintaining their anti-tumorigenic effect. Interestingly, vitamin $\mathrm{D}_{3}$ does not only reduce harmful GvHD effects but also exerts anti-tumor activity. So far, scientific literature supporting this assumption in the transplantation setting remains sparse. However, a few studies provide indications for its hypothetical anti-cancer effects. In their retrospective study, Radujkovic et al. could demonstrate that pre-transplant vitamin $\mathrm{D}_{3}$ deficiency in patients diagnosed with myeloid malignancies correlates with a higher risk of relapse mortality (94). To our knowledge, only three other studies have also investigated this association $(90,95,96)$. So far, only one study included few patients which underwent autologous transplantation (97). However, they only figured out that sufficient vitamin $\mathrm{D}_{3}$ levels are hard to achieve. In summary, these data suggest that prospective randomized trials have to prove whether vitamin $\mathrm{D}_{3}$ supplementation during stem cell transplantation could enhance GvL effects.

\section{Vitamin $D_{3}$ and Cancer}

The first correlation of solar radiation and cancer was initially suggested by Apperly in 1941, who attributed sunlight radiation a protective role against many types of cancer except skin 
cancer (98). Decades later, Colston et al. were the first ones to show a dose-dependent inhibitory effect of $1,25(\mathrm{OH})_{2} \mathrm{D}_{3}$ on melanoma cells $(99,100)$. Epidemiological studies provide evidence that poor sunlight exposure and vitamin $\mathrm{D}_{3}$ deficiency correlate directly with incidence as well as mortality rate of several cancer types. These findings suggest a protective role of vitamin $\mathrm{D}_{3}$ in carcinogenesis (101). Accumulating studies have revealed that $1,25(\mathrm{OH})_{2} \mathrm{D}_{3}$ suppresses tumor growth (102104) and exhibits anti-proliferative activities in squamous cell carcinoma (105), prostate (106), breast (107, 108), lung (109), head and neck cancer (110) and hematologic malignancies such as Hodgkin's lymphoma (111) or chronic lymphocytic leukemia (CLL) (112). In colorectal cancer, a clinical trial provides evidence that $1,25(\mathrm{OH})_{2} \mathrm{D}_{3}$ supplementation can efficiently reduce the risk of tumor development (113). However, other epidemiological studies report contradictory results (114-116), which might be a result of using supra-physiological concentrations of calcitriol (117), VDR gene polymorphisms (118), lack of control groups or inappropriate dosage and administration of vitamin $\mathrm{D}_{3}$.

Apart from the discovery that sufficient vitamin $\mathrm{D}_{3}$ supplementation could help to prevent cancer pathogenesis, numerous in vitro and in vivo studies provide evidence that $1,25(\mathrm{OH})_{2} \mathrm{D}_{3}$ and its analogs could reduce tumor growth and might be used as potential anticancer agent (15, 119-121). Supporting this, animal studies report that VDR-deletion in mice makes them more susceptible to chemical induced carcinogenesis in epidermis, lymphoid and mammary tissue (122). Interestingly, life expectancy of leukemic mice could be prolonged by treatment with a $1,25(\mathrm{OH})_{2} \mathrm{D}_{3}$ analog (123). A chemoprevention study revealed that $1,25(\mathrm{OH})_{2} \mathrm{D}_{3}$-treated Nkx3.1;Pten mutant mice show retarded development of neoplasias when it was administered during early-stage carcinogenesis (124).

There is clear evidence that cancer cells exploit and dysregulate the vitamin $\mathrm{D}_{3}$ metabolism enabling them to escape its cancer protective role (15). CYP24A1 has been shown to be overexpressed in cancer cells while activity of CYP27B1 is reduced in human prostate cancer cells $(125,126)$. Furthermore, CYP24A1 was identified as potential oncogene in breast cancer and elevated expression of VDR in tissues of breast and prostate cancer correlates with better prognosis of survival (127).

\section{Mechanisms of Anti-tumorigenic Actions}

Although the precise mechanisms of vitamin $\mathrm{D}_{3}$-mediated antitumorigenic action are not yet fully understood, it has been postulated that vitamin $\mathrm{D}_{3}$ modulates gene expression involved in apoptosis, cell cycle and autophagy in tumor cells (128). Apoptosis is initiated due to downregulation of anti-apoptotic protein $\mathrm{Bcl} 2$ while expression of pro-apoptotic proteins increases (129). Jiang et al. suggest that $1,25(\mathrm{OH})_{2} \mathrm{D}_{3}$ induces cell death by degrading telomerase reverse transcriptase (TERT) mRNA and thus reduces telomerase activity (130). 1,25(OH) ${ }_{2} \mathrm{D}_{3}$-induced upregulation of p21 and p27, which are cyclin-dependent kinase (CDK) inhibitors, induces cell cycle arrest (121, 129, 131). Furthermore, vitamin $\mathrm{D}_{3}$ mediates anti-proliferative activity by enhancing expression of Dickkopf-1 (DKK-1), which is an antagonist in the $\mathrm{Wnt} / \beta$-catenin signaling pathway (132). In vitro as well as in vivo studies report inhibition of proliferation and angiogenesis by vitamin $\mathrm{D}_{3}$. It suppresses hypoxia-inducible factor 1-alpha (HIF1A) leading to reduced expression of vascular endothelial growth factor (VEGF) and thereby inhibition of angiogenesis $(133,134)$. Autophagy is not only triggered in infected macrophages, but also in tumor cells such as breast cancer. Since autophagy appears to protect healthy tissue from cancer initiation, vitamin $\mathrm{D}_{3}$-treatment might contribute to suppression of carcinogenesis (135). It also increases activity of antioxidant enzymes such as superoxide dismutase 1/2 (SOD1/2) and therefore protects DNA from ROS-induced damage (129). Upon vitamin $\mathrm{D}_{3}$ administration, DNA damage repair proteins, such as $\mathrm{p} 53$, are upregulated in vitro (15).

Strikingly, anti-tumor activity of tumor-associated macrophages (TAMs) against lymphomas has been shown to be enhanced by vitamin $\mathrm{D}_{3}$-triggered increase of antibodydependent cellular toxicity (ADCC) and antibody-dependent cellular phagocytosis (ADCP) (136). Current observations of Busch et al. reveal that combination of vitamin $\mathrm{D}_{3}$ with immunomodulatory drugs (IMiDs), such as lenalidomide, helps to restore the defective vitamin $\mathrm{D}_{3}$ metabolism in myeloma-associated macrophages and improves cytotoxicity against multiple myeloma cells mediated by specific anti-CD38 antibodies such as MOR202 $(137,138)$. Furthermore, exosomal transfer of microRNAs, which induce tumor-promoting myeloid-derived suppressor cells, was impeded by vitamin $\mathrm{D}_{3}$ (139). The previously mentioned cathelicidin, which is secreted by human macrophages, has also been shown to mediate direct anti-tumor efficacy against high-grade B cell lymphoma by increasing ADCC (136). In summary, there is strong evidence that vitamin $\mathrm{D}_{3}$ exerts direct anti-tumorigenic functions which might be applicable in allo-HSCT patients in order to boost GvL effects.

\section{Mediation of Anti-inflammation to Antagonize Carcinogenesis}

In 1863, Virchow postulated for the first time that tissue proliferation and hence tumor progression might be provoked by an inflammatory microenvironment connecting cancer with inflammation $(140,141)$. Since inflammatory tissue provides ideal conditions for genetic mutations, it seems obvious that tumor progression occurs more frequently in inflammatory environment than in healthy tissue. Clinical studies proved that localized persistent inflammation is a risk factor for the development of cancer in adjacent organs, e.g., patients with ulcerative colitis have a higher incidence of colorectal cancer (142). Given that inflammation promotes carcinogenesis, vitamin $\mathrm{D}_{3}$-dependent anti-inflammatory activity could reduce tumor progression. In esophageal squamous cell carcinoma, $1,25(\mathrm{OH})_{2} \mathrm{D}_{3}$ impedes tumor growth by inhibition of IL-6 signaling (117). Accumulating data report that $1,25(\mathrm{OH})_{2} \mathrm{D}_{3}$ inhibits prostaglandin (PG) (143), p38 MAPK (144) and nuclear factor kappa $\mathrm{B}(\mathrm{NF \kappa} \mathrm{B})$ signaling pathways (15). Although there is increasing evidence for inflammation-driven carcinogenesis, not every type of chronic inflammation evokes tumor development, which appears to be contradictory. 


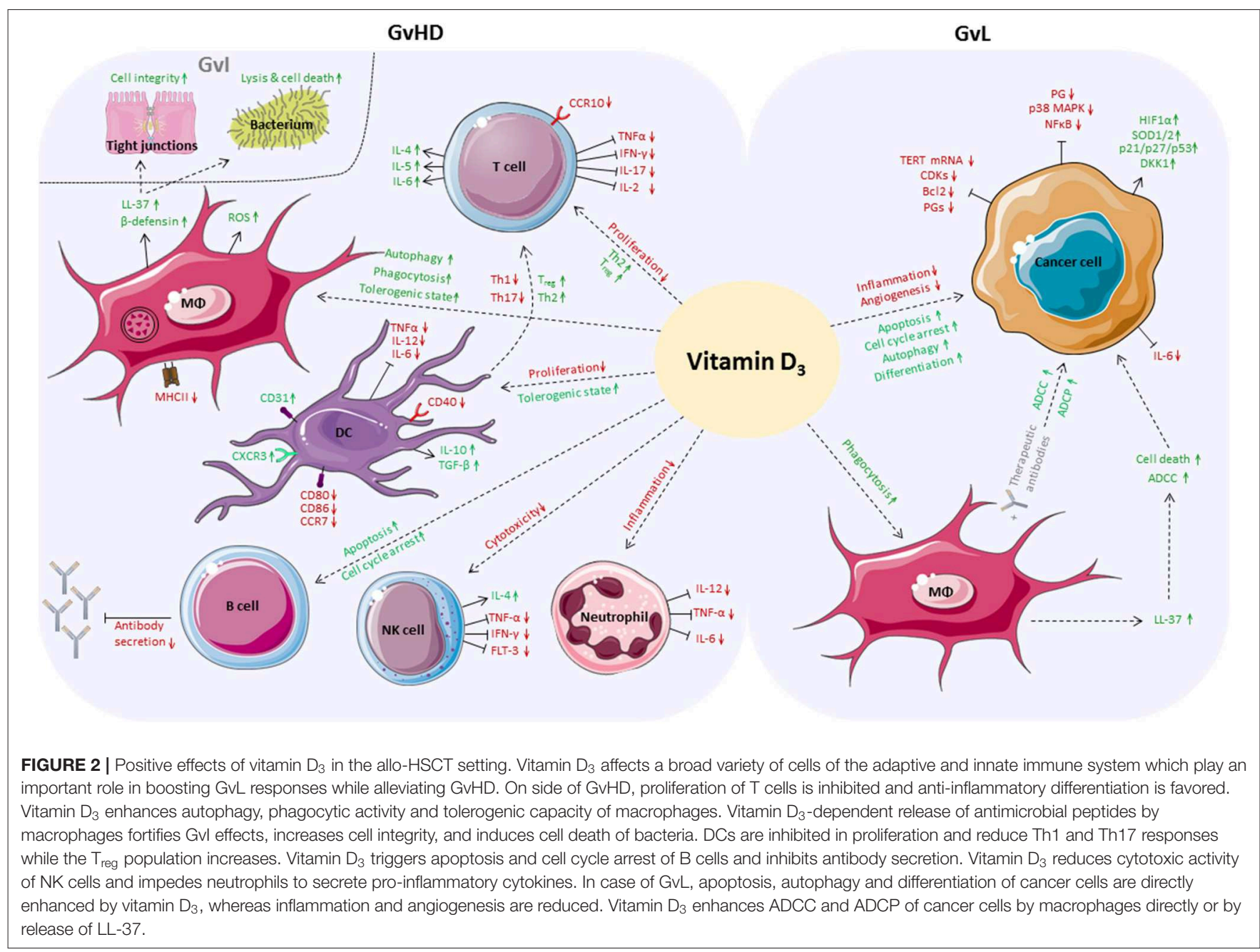

Despite the well-founded evidence of anti-tumorigenic effects of vitamin $\mathrm{D}_{3}$ in solid tumors, studies on hematological malignancies remain elusive. Given that vitamin $\mathrm{D}_{3}$ deficiency correlates with worse relapse-free survival (94-96) and the known anti-tumorigenic effects of vitamin $\mathrm{D}_{3}$, one might think that it could also enhance GvL. By using mice fed with low and high vitamin $\mathrm{D}_{3}$ doses or by performing clinical trials with vitamin $\mathrm{D}_{3}$ supplementation, the actual effect on GvL could be investigated.

\section{CONCLUSION/PERSPECTIVES}

In summary, we assume that vitamin $\mathrm{D}_{3}$ could be a potential immune modulating agent for supplementation before and during allo-HSCT. It is conceivable that vitamin $\mathrm{D}_{3}$ might be able to maintain and improve the patient's immune balance and epithelial barrier function. Mounting evidence indicates that vitamin $\mathrm{D}_{3}$ could alleviate $\mathrm{GvHD}$ by enhancing antiinflammatory responses while it might coincidently ameliorate GvI effects due to its anti-microbial activities. Moreover, GvL might be boosted because vitamin $\mathrm{D}_{3}$ could at least reinforce anti-tumorigenic responses of myeloid cells (Figure 2).
Besides its easy availability, economy and role in preserving the intestinal barrier integrity (53), vitamin $\mathrm{D}_{3}$ helps to maintain calcium and bone homeostasis and hence prevents osteoporosis. Given that allo-HSCT patients often suffer from bone loss upon conditioning regimens, immunosuppressive treatment and immobilization, it might also improve GvHD by preventing osteoporosis (34). Cholecalciferol can usually be administered safely in high doses without occurrence of abnormal calcium metabolism (145). However, sufficient vitamin $\mathrm{D}_{3}$ levels cannot be achieved in all patients despite high-dose supplementation (97). Therefore, treatment with $1,25(\mathrm{OH})_{2} \mathrm{D}_{3}$ might be the more efficient version. However, the probably greatest restraining factor of $1,25(\mathrm{OH})_{2} \mathrm{D}_{3}$ is its doselimiting toxicity causing hypercalcemia and hypercalciuria. One possible solution might be the administration of $1,25(\mathrm{OH})_{2} \mathrm{D}_{3}$ analogs, some of which have already been shown to be less calcemic $(146,147)$.

Until now, only few clinical trials with vitamin $\mathrm{D}_{3}$ in the allo-HSCT setting have been conducted and have shown effective outcomes (90). The most recent study of CarilloCruz et al. suggests that universal vitamin $\mathrm{D}_{3}$ medication remains challenging due to VDR polymorphisms (29). Our 
hypothesis that vitamin $\mathrm{D}_{3}$ could improve GvL might seem controversial due to its known anti-inflammatory activities on $\mathrm{T}$ cells. However, it was shown by Essen et al. that TCR signaling in naïve human $\mathrm{T}$ cells induces VDR expression (148). This in turn results in upregulated PLC- $\gamma 1$ expression and thus higher activation and priming of naïve $\mathrm{T}$ cells. Although there is evidence that vitamin $\mathrm{D}_{3}$ attenuates IL6 signaling in human esophageal squamous cell carcinoma (SCC) cell lines (117), the in vivo study of Bendix-Struve and colleagues demonstrated that $\mathrm{T}$ cells of vitamin $\mathrm{D}_{3}$-supplemented Crohn's disease (CD) patients produced more IL-6 (149). Proliferation of $\mathrm{CD} 4+\mathrm{T}$ cells was higher in vitamin $\mathrm{D}_{3}$-treated patients compared to the placebo group. Additionally, VDR was shown to be important for the development of CD8 $\alpha \alpha+$ TCR $\alpha \beta+$ cells, which help to maintain tolerance in the gut and suppress intestinal inflammation (150). Expression of the guthoming receptor CCR9 is suppressed in T cells upon vitamin $\mathrm{D}_{3}$ stimulation, which might prevent homing of potential alloreactive $\mathrm{T}$ cells into the gut. However, these data provide only indications that vitamin $\mathrm{D}_{3}$ might promote $\mathrm{GvL}$ despite its anti-inflammatory properties.

\section{REFERENCES}

1. Majhail NS, Farnia SH, Carpenter PA, Champlin RE, Crawford S, Marks DI, et al. Indications for autologous and allogeneic hematopoietic cell transplantation: guidelines from the American Society for Blood and Marrow Transplantation. Biol Blood Marrow Transplant. (2015) 21:1863-9. doi: 10.1016/j.bbmt.2015.07.032

2. Kolb HJ. Graft-versus-leukemia effects of transplantation and donor lymphocytes. Blood. (2008) 112:4371-83. doi: 10.1182/blood-2008-03-077974

3. Ogonek J, Kralj Juric M, Ghimire S, Varanasi PR, Holler $\mathrm{E}$, Greinix $\mathrm{H}$, et al. Immune reconstitution after allogeneic hematopoietic stem cell transplantation. Front Immunol. (2016) 7:507. doi: 10.3389/fimmu.2016.00507

4. Li JM, Giver CR, Lu Y, Hossain MS, Akhtari M, Waller EK. Separating graftversus-leukemia from graft-versus-host disease in allogeneic hematopoietic stem cell transplantation. Immunotherapy. (2009) 1:599-621.

5. Martin PJ, Rizzo JD, Wingard JR, Ballen K, Curtin PT, Cutler C, et al. First- and second-line systemic treatment of acute graft-versushost disease: recommendations of the American Society of Blood and Marrow Transplantation. Biol Blood Marrow Transplant. (2012) 18:1150-63. doi: 10.1016/j.bbmt.2012.04.005

6. Datta A, David R, Glennie S, Scott D, Cernuda-Morollon E, Lechler RI, et al. Differential effects of immunosuppressive drugs on T-cell motility. Am J Transplant. (2006) 6:2871-83. doi: 10.1111/j.1600-6143.2006. 01553.x

7. Adorini L, Giarratana N, Penna G. Pharmacological induction of tolerogenic dendritic cells and regulatory T cells. Semin Immunol. (2004) 16:127-34. doi: 10.1016/j.smim.2003.12.008

8. Chang YJ, Zhao XY, Huang XJ. Strategies for enhancing and preserving anti-leukemia effects without aggravating graft-versushost disease. Front Immunol. (2018) 9:3041. doi: 10.3389/fimmu.2018. 03041

9. Deluca HF. History of the discovery of vitamin D and its active metabolites. Bonekey Rep. (2014) 3:479. doi: 10.1038/bonekey.2013.213

10. Kreutz M, Andreesen R, Krause SW, Szabo A, Ritz E, Reichel H. 1,25dihydroxyvitamin D3 production and vitamin D3 receptor expression are developmentally regulated during differentiation of human monocytes into macrophages. Blood. (1993) 82:1300-7. doi: 10.1182/blood.V82.4.1300.1300
In conclusion, prospective in vivo studies in humans are inevitable to investigate the efficacy of vitamin $\mathrm{D}_{3}$ supplementation and to achieve approved clinical application.

\section{AUTHOR CONTRIBUTIONS}

CF wrote the manuscript and created the figures. HB took the lead in writing the manuscript. MK and KP provided critical feedback, contributed to the final version of the manuscript, and approved it for publication.

\section{FUNDING}

HB was supported by Wilhelm-Sander Foundation. HB, CF, KP, and MK were funded by the Deutsche Forschungsgemeinschaft (DFG, German Research Foundation) - B12- TRR 221.

\section{ACKNOWLEDGMENTS}

Illustrations for figures were obtained from https://smart. servier.com.

11. Fritsche J, Mondal K, Ehrnsperger A, Andreesen R, Kreutz M. Regulation of 25-hydroxyvitamin D3-1 alpha-hydroxylase and production of 1 alpha,25dihydroxyvitamin D3 by human dendritic cells. Blood. (2003) 102:3314-6. doi: 10.1182/blood-2002-11-3521

12. Gottfried E, Rehli M, Hahn J, Holler E, Andreesen R, Kreutz M. Monocyte-derived cells express CYP27A1 and convert vitamin D3 into its active metabolite. Biochem Biophys Res Commun. (2006) 349:209-13. doi: 10.1016/j.bbrc.2006.08.034

13. Prietl B, Treiber G, Pieber TR, Amrein K. Vitamin D and immune function. Nutrients. (2013) 5:2502-21. doi: 10.3390/nu5072502

14. Bruns H, Stenger S. New insights into the interaction of Mycobacterium tuberculosis and human macrophages. Future Microbiol. (2014) 9:327-41. doi: $10.2217 /$ fmb.13.164

15. Jeon SM, Shin EA. Exploring vitamin D metabolism and function in cancer. Exp Mol Med. (2018) 50:20. doi: 10.1038/s12276-018-0038-9

16. Kamen DL, Tangpricha V. Vitamin D and molecular actions on the immune system: modulation of innate and autoimmunity. J Mol Med. (2010) 88:44150. doi: 10.1007/s00109-010-0590-9

17. Munger KL, Ascherio A. Prevention and treatment of MS: studying the effects of vitamin Mult Scler D. (2011) 17:1405-11. doi: $10.1177 / 1352458511425366$

18. Hassanalilou T, Khalili L, Ghavamzadeh S, Shokri A, Payahoo L, Bishak YK. Role of vitamin D deficiency in systemic lupus erythematosus incidence and aggravation. Auto Immun Highlights. (2017) 9:1. doi: 10.1007/s13317-017-0101-x

19. Cantorna MT, Mahon BD. Mounting evidence for vitamin D as an environmental factor affecting autoimmune disease prevalence. Exp Biol Med. (2004) 229:1136-42. doi: 10.1177/153537020422901108

20. Yang J, Liu L, Zhang Q, Li M, Wang J. Effect of vitamin D on the recurrence rate of rheumatoid arthritis. Exp Ther Med. (2015) 10:1812-6. doi: $10.3892 /$ etm.2015.2747

21. Kim D. The role of vitamin D in thyroid diseases. Int J Mol Sci. (2017) 18:1949. doi: 10.3390/ijms18091949

22. Czaja AJ, Montano-Loza AJ. Evolving role of vitamin D in immune-mediated disease and its implications in autoimmune hepatitis. Dig Dis Sci. (2019) 64:324-44. doi: 10.1007/s10620-018-5351-6

23. Johnsson C, Tufveson G. MC 1288-a vitamin D analogue with immunosuppressive effects on heart and small bowel grafts. Transpl Int. (1994) 7:392-7. doi: 10.1007/BF00346032 
24. Lewin $\mathrm{E}$, Olgaard $\mathrm{K}$. The in vivo effect of a new, in vitro, extremely potent vitamin D3 analog KH1060 on the suppression of renal allograft rejection in the rat. Calcif Tissue Int. (1994) 54:150-4. doi: 10.1007/BF00296066

25. Hullett DA, Cantorna MT, Redaelli C, Humpal-Winter J, Hayes CE, Sollinger HW, et al. Prolongation of allograft survival by 1,25-dihydroxyvitamin D3. Transplantation. (1998) 66:824-8. doi: 10.1097/00007890-199810150-00002

26. Pakkala I, Taskinen E, Pakkala S, Raisanen-Sokolowski A. MC1288, a vitamin $\mathrm{D}$ analog, prevents acute graft-versus-host disease in rat bone marrow transplantation. Bone Marrow Transplant. (2001) 27:863-7. doi: $10.1038 /$ sj.bmt.1702873

27. Middleton PG, Cullup H, Dickinson AM, Norden J, Jackson GH, Taylor $\mathrm{PR}$, et al. Vitamin D receptor gene polymorphism associates with graft-versus-host disease and survival in HLA-matched sibling allogeneic bone marrow transplantation. Bone Marrow Transplant. (2002) 30:223-8. doi: 10.1038/sj.bmt.1703629

28. Rocha V, Porcher R, Fernandes JF, Filion A, Bittencourt H, Silva W Jr, et al. Association of drug metabolism gene polymorphisms with toxicities, graftversus-host disease and survival after HLA-identical sibling hematopoietic stem cell transplantation for patients with leukemia. Leukemia. (2009) 23:545-56. doi: 10.1038/leu.2008.323

29. Carrillo-Cruz E, Garcia-Lozano JR, Marquez-Malaver FJ, Sanchez-Guijo FM, Montero Cuadrado I, Ferra ICC, et al. Vitamin D modifies the incidence of graft-versus-host disease after allogeneic stem cell transplantation depending on the vitamin D receptor (VDR) polymorphisms. Clin Cancer Res. (2019) 25:4616-23. doi: 10.1158/1078-0432.CCR-18-3875

30. Ros-Soto J, Anthias C, Madrigal A, Snowden JA. Vitamin D: is it important in haematopoietic stem cell transplantation? A review. Bone Marrow Transplant. (2018) 54:810-20. doi: 10.1038/s41409-018-0377-0

31. Kreutz M, Eissner G, Hahn J, Andreesen R, Drobnik W, Holler E. Variations in 1 alpha,25-dihydroxyvitamin D3 and 25-hydroxyvitamin D3 serum levels during allogeneic bone marrow transplantation. Bone Marrow Transplant. (2004) 33:871-3. doi: 10.1038/sj.bmt.1704448

32. Beebe K, Magee K, McNulty A, Stahlecker J, Salzberg D, Miller H, et al. Vitamin D deficiency and outcomes in pediatric hematopoietic stem cell transplantation. Pediatr Blood Cancer. (2018) 65:e26817. doi: $10.1002 /$ pbc. 26817

33. Glotzbecker B, Ho VT, Aldridge J, Kim HT, Horowitz G, Ritz J, et al. Low levels of 25-hydroxyvitamin D before allogeneic hematopoietic SCT correlate with the development of chronic GVHD. Bone Marrow Transplant. (2013) 48:593-7. doi: 10.1038/bmt.2012.177

34. Sproat L, Bolwell B, Rybicki L, Dean R, Sobecks R, Pohlman B, et al. Vitamin D level after allogeneic hematopoietic stem cell transplant. Biol Blood Marrow Transplant. (2011) 17:1079-83. doi: 10.1016/j.bbmt.2010.12.704

35. Chen X, Mayne CG. The role of micronutrients in graft-vs.-host disease: immunomodulatory effects of vitamins A and D. Front Immunol. (2018) 9:2853. doi: 10.3389/fimmu.2018.02853

36. Brighenti S, Bergman P, Martineau AR. Vitamin D and tuberculosis: where next? J Intern Med. (2018) 284:145-62. doi: 10.1111/joim.12777

37. Green M. Cod liver oil and tuberculosis. BMJ. (2011) 343:d7505. doi: 10.1136/bmj.d7505

38. Rook GA, Steele J, Fraher L, Barker S, Karmali R, O’Riordan J, et al. Vitamin D3, gamma interferon, and control of proliferation of Mycobacterium tuberculosis by human monocytes. Immunology. (1986) 57:159-63.

39. Crowle AJ, Ross EJ, May MH. Inhibition by 1,25(OH)2-vitamin D3 of the multiplication of virulent tubercle bacilli in cultured human macrophages. Infect Immun. (1987) 55:2945-50. doi: 10.1016/0041-3879(88)90036-0

40. Fabri M, Stenger S, Shin DM, Yuk JM, Liu PT, Realegeno S, et al. Vitamin $\mathrm{D}$ is required for IFN-gamma-mediated antimicrobial activity of human macrophages. Sci Transl Med. (2011) 3:104ra102. doi: 10.1126/scitranslmed.3003045

41. Wang TT, Nestel FP, Bourdeau V, Nagai Y, Wang Q, Liao J, et al. Cutting edge: 1,25-dihydroxyvitamin D3 is a direct inducer of antimicrobial peptide gene expression. J Immunol. (2004) 173:2909-12. doi: 10.4049/jimmunol.173.5.2909

42. Gombart AF, Borregaard N, Koeffler HP. Human cathelicidin antimicrobial peptide (CAMP) gene is a direct target of the vitamin $\mathrm{D}$ receptor and is strongly up-regulated in myeloid cells by 1,25 -dihydroxyvitamin D3. FASEB J. (2005) 19:1067-77. doi: 10.1096/fj.04-3284com
43. Martineau AR, Wilkinson KA, Newton SM, Floto RA, Norman AW, Skolimowska K, et al. IFN-gamma- and TNF-independent vitamin Dinducible human suppression of mycobacteria: the role of cathelicidin LL-37. J Immunol. (2007) 178:7190-8. doi: 10.4049/jimmunol.178. 11.7190

44. Leszczynska K, Namiot D, Byfield FJ, Cruz K, Zendzian-Piotrowska M, Fein DE, et al. Antibacterial activity of the human host defence peptide LL-37 and selected synthetic cationic lipids against bacteria associated with oral and upper respiratory tract infections. J Antimicrob Chemother. (2013) 68:610-8. doi: $10.1093 / \mathrm{jac} / \mathrm{dks} 434$

45. Hansdottir S, Monick MM, Hinde SL, Lovan N, Look DC, Hunninghake GW. Respiratory epithelial cells convert inactive vitamin D to its active form: potential effects on host defense. J Immunol. (2008) 181:7090-9. doi: 10.4049/jimmunol.181.10.7090

46. van der Does AM, Bergman P, Agerberth B, Lindbom L. Induction of the human cathelicidin LL-37 as a novel treatment against bacterial infections. $J$ Leukoc Biol. (2012) 92:735-42. doi: 10.1189/jlb.0412178

47. Wan M, van der Does AM, Tang X, Lindbom L, Agerberth B, Haeggstrom JZ. Antimicrobial peptide LL-37 promotes bacterial phagocytosis by human macrophages. J Leukoc Biol. (2014) 95:971-81. doi: 10.1189/jlb.0513304

48. Alalwani SM, Sierigk J, Herr C, Pinkenburg O, Gallo R, Vogelmeier C, et al. The antimicrobial peptide LL-37 modulates the inflammatory and host defense response of human neutrophils. Eur J Immunol. (2010) 40:1118-26. doi: 10.1002/eji.200939275

49. Choi H, Yang Z, Weisshaar JC. Oxidative stress induced in E. coli by the human antimicrobial peptide LL-37. PLoS Pathog. (2017) 13:e1006481. doi: 10.1371/journal.ppat.1006481

50. Yuk JM, Shin DM, Lee HM, Yang CS, Jin HS, Kim KK, et al. Vitamin D3 induces autophagy in human monocytes/macrophages via cathelicidin. Cell Host Microbe. (2009) 6:231-43. doi: 10.1016/j.chom.2009.08.004

51. Barlow PG, Svoboda P, Mackellar A, Nash AA, York IA, Pohl J, et al. Antiviral activity and increased host defense against influenza infection elicited by the human cathelicidin LL-37. PLoS ONE. (2011) 6:e25333. doi: 10.1371/journal.pone.0025333

52. Lopez-Garcia B, Lee PH, Yamasaki K, Gallo RL. Anti-fungal activity of cathelicidins and their potential role in Candida albicans skin infection. $J$ Invest Dermatol. (2005) 125:108-15. doi: 10.1111/j.0022-202X.2005.23713.x

53. Kong J, Zhang Z, Musch MW, Ning G, Sun J, Hart J, et al. Novel role of the vitamin $\mathrm{D}$ receptor in maintaining the integrity of the intestinal mucosal barrier. Am J Physiol Gastrointest Liver Physiol. (2008) 294:G208-16. doi: 10.1152/ajpgi.00398.2007

54. Zhang YG, Wu S, Lu R, Zhou D, Zhou J, Carmeliet G, et al. Tight junction CLDN2 gene is a direct target of the vitamin D receptor. Sci Rep. (2015) 5:10642. doi: 10.1038/srep10642

55. Nalle SC, Turner JR. Intestinal barrier loss as a critical pathogenic link between inflammatory bowel disease and graft-versus-host disease. Mucosal Immunol. (2015) 8:720-30. doi: 10.1038/mi.2015.40

56. Chen X, Zou X, Qi G, Tang Y, Guo Y, Si J, et al. Roles and mechanisms of human cathelicidin LL-37 in cancer. Cell Physiol Biochem. (2018) 47:106073. doi: $10.1159 / 000490183$

57. Sun L, Wang W, Xiao W, Yang H. The roles of cathelicidin LL-37 in inflammatory bowel disease. Inflamm Bowel Dis. (2016) 22:1986-91. doi: 10.1097/MIB.0000000000000804

58. Kirikae T, Hirata M, Yamasu H, Kirikae F, Tamura H, Kayama F, et al. Protective effects of a human 18-kilodalton cationic antimicrobial protein (CAP18)-derived peptide against murine endotoxemia. Infect Immun. (1998) 66:1861-8.

59. Ferrara JL, Levine JE, Reddy P, Holler E. Graft-versus-host disease. Lancet. (2009) 373:1550-61. doi: 10.1016/S0140-6736(09)60237-3

60. Kreutz M, Andreesen R. Induction of human monocyte to macrophage maturation in vitro by 1,25-dihydroxyvitamin D3. Blood. (1990) 76:2457-61. doi: 10.1182/blood.V76.12.2457.bloodjournal76122457

61. Rigby WF, Waugh M, Graziano RF. Regulation of human monocyte HLA-DR and CD4 antigen expression, and antigen presentation by 1,25-dihydroxyvitamin D3. Blood. (1990) 76:189-97. doi: 10.1182/blood.V76.1.189.bloodjournal761189

62. Zhu X, Zhu Y, Li C, Yu J, Ren D, Qiu S, et al. 1,25Dihydroxyvitamin $\mathrm{D}$ regulates macrophage polarization and ameliorates experimental 
inflammatory bowel disease by suppressing miR-125b. Int Immunopharmacol. (2019) 67:106-18. doi: 10.1016/j.intimp.2018.12.015

63. Berer A, Stockl J, Majdic O, Wagner T, Kollars M, Lechner $\mathrm{K}$, et al. 1,25-Dihydroxyvitamin $\mathrm{D}(3)$ inhibits dendritic cell differentiation and maturation in vitro. Exp Hematol. (2000) 28:575-83. doi: $10.1016 / \mathrm{S} 0301-472 \mathrm{X}(00) 00143-0$

64. Ferreira GB, Gysemans CA, Demengeot J, da Cunha JP, Vanherwegen AS, Overbergh L, et al. 1,25-Dihydroxyvitamin D3 promotes tolerogenic dendritic cells with functional migratory properties in NOD mice. $J$ Immunol. (2014) 192:4210-20. doi: 10.4049/jimmunol.1302350

65. Penna G, Adorini L. 1 Alpha,25-dihydroxyvitamin D3 inhibits differentiation, maturation, activation, and survival of dendritic cells leading to impaired alloreactive T cell activation. J Immunol. (2000) 164:2405-11. doi: 10.4049/jimmunol.164.5.2405

66. Almerighi C, Sinistro A, Cavazza A, Ciaprini C, Rocchi G, Bergamini A. 1Alpha,25-dihydroxyvitamin D3 inhibits CD40L-induced pro-inflammatory and immunomodulatory activity in human monocytes. Cytokine. (2009) 45:190-7. doi: 10.1016/j.cyto.2008.12.009

67. Saul L, Mair I, Ivens A, Brown P, Samuel K, Campbell JDM, et al. 1,25-Dihydroxyvitamin D3 Restrains CD4(+) T Cell Priming Ability of $\mathrm{CD} 11 \mathrm{c}(+)$ Dendritic Cells by Upregulating Expression of CD31. Front Immunol. (2019) 10:600. doi: 10.3389/fimmu.2019.00600

68. D’Ambrosio D, Cippitelli M, Cocciolo MG, Mazzeo D, Di Lucia P, Lang $\mathrm{R}$, et al. Inhibition of IL-12 production by 1,25-dihydroxyvitamin D3. Involvement of NF-kappaB downregulation in transcriptional repression of the p40 gene. J Clin Invest. (1998) 101:252-62. doi: 10.1172/JCI1050

69. Vanherwegen AS, Cook DP, Ferreira GB, Gysemans C, Mathieu C. Vitamin D-modulated dendritic cells delay lethal graft-versus-host disease through induction of regulatory T cells. J Steroid Biochem Mol Biol. (2019) 188:03-10. doi: 10.1016/j.jsbmb.2018.12.013

70. Gregori S, Casorati M, Amuchastegui S, Smiroldo S, Davalli AM, Adorini L. Regulatory $\mathrm{T}$ cells induced by 1 alpha,25-dihydroxyvitamin D3 and mycophenolate mofetil treatment mediate transplantation tolerance. $J$ Immunol. (2001) 167:1945-53. doi: 10.4049/jimmunol.167.4.1945

71. Zhou L, Wang J, Li J, Li T, Chen Y, June RR, et al. 1,25-Dihydroxyvitamin D3 ameliorates collagen-induced arthritis via suppression of Th17 cells through miR-124 mediated inhibition of IL-6 signaling. Front Immunol. (2019) 10:178. doi: 10.3389/fimmu.2019.00178

72. Xu Y, Cheng Y, Baylink DJ, Wasnik S, Goel G, Huang M, et al. In vivo generation of gut-homing regulatory $\mathrm{T}$ cells for the suppression of colitis. J Immunol. (2019) 202:3447-57. doi: 10.4049/jimmunol.1800018

73. Vanherwegen AS, Eelen G, Ferreira GB, Ghesquiere B, Cook DP, Nikolic T, et al. Vitamin D controls the capacity of human dendritic cells to induce functional regulatory T cells by regulation of glucose metabolism. J Steroid Biochem Mol Biol. (2019) 187:134-45. doi: 10.1016/j.jsbmb.2018.11.011

74. Coussens A, Timms PM, Boucher BJ, Venton TR, Ashcroft AT, Skolimowska $\mathrm{KH}$, et al. 1alpha,25-dihydroxyvitamin D3 inhibits matrix metalloproteinases induced by Mycobacterium tuberculosis infection. Immunology. (2009) 127:539-48. doi: 10.1111/j.1365-2567.2008.03024.x

75. Coussens AK, Wilkinson RJ, Hanifa Y, Nikolayevskyy V, Elkington PT, Islam K, et al. Vitamin D accelerates resolution of inflammatory responses during tuberculosis treatment. Proc Natl Acad Sci USA. (2012) 109:15449-54. doi: 10.1073/pnas.1200072109

76. Olson KC, Kulling Larkin PM, Signorelli R, Hamele CE, Olson TL, Conaway MR, et al. Vitamin D pathway activation selectively deactivates signal transducer and activator of transcription (STAT) proteins and inflammatory cytokine production in natural killer leukemic large granular lymphocytes. Cytokine. (2018) 111:551-62. doi: 10.1016/j.cyto.2018. 09.016

77. Carniti C, Gimondi S, Vendramin A, Recordati C, Confalonieri D, Bermema A, et al. Pharmacologic inhibition of JAK1/JAK2 signaling reduces experimental murine acute GVHD while preserving GVT effects. Clin Cancer Res. (2015) 21:3740-9. doi: 10.1158/1078-0432.CCR-14-2758

78. Zeiser R, Burchert A, Lengerke C, Verbeek M, Maas-Bauer K, Metzelder SK, et al. Ruxolitinib in corticosteroid-refractory graft-versus-host disease after allogeneic stem cell transplantation: a multicenter survey. Leukemia. (2015) 29:2062-8. doi: 10.1038/leu.2015.212
79. Spoerl S, Mathew NR, Bscheider M, Schmitt-Graeff A, Chen S, Mueller T, et al. Activity of therapeutic JAK $1 / 2$ blockade in graft-versus-host disease. Blood. (2014) 123:3832-42. doi: 10.1182/blood-2013-12-543736

80. Young JA. Infectious complications of acute and chronic GVHD. Best Pract Res Clin Haematol. (2008) 21:343-56. doi: 10.1016/j.beha.2008.02.017

81. Fuji S, Kapp M, Einsele H. Possible implication of bacterial infection in acute graft-versus-host disease after allogeneic hematopoietic stem cell transplantation. Front Oncol. (2014) 4:89. doi: 10.3389/fonc.2014.00089

82. Rosenblatt J, Bissonnette A, Ahmad R, Wu Z, Vasir B, Stevenson K, et al. Immunomodulatory effects of vitamin D: implications for GVHD. Bone Marrow Transplant. (2010) 45:1463-8. doi: 10.1038/bmt.2009.366

83. Provvedini DM, Tsoukas CD, Deftos LJ, Manolagas SC. 1,25dihydroxyvitamin D3 receptors in human leukocytes. Science. (1983) 221:1181-3. doi: 10.1126/science.6310748

84. Jeffery LE, Burke F, Mura M, Zheng Y, Qureshi OS, Hewison M, et al. 1,25-Dihydroxyvitamin D3 and IL-2 combine to inhibit T cell production of inflammatory cytokines and promote development of regulatory $\mathrm{T}$ cells expressing CTLA-4 and FoxP3. J Immunol. (2009) 183:5458-67. doi: 10.4049/jimmunol.0803217

85. Vanham G, Ceuppens JL, Bouillon R. T lymphocytes and their CD4 subset are direct targets for the inhibitory effect of calcitriol. Cell Immunol. (1989) 124:320-33. doi: 10.1016/0008-8749(89)90134-2

86. Baeke F, Korf H, Overbergh L, van Etten E, Verstuyf A, Gysemans C, et al. Human T lymphocytes are direct targets of 1,25-dihydroxyvitamin D3 in the immune system. J Steroid Biochem Mol Biol. (2010) 121:221-7. doi: 10.1016/j.jsbmb.2010.03.037

87. Zhang Z, Chen F, Li J, Luo F, Hou T, Xu J, et al. 1,25(OH)2D3 suppresses proinflammatory responses by inhibiting Th1 cell differentiation and cytokine production through the JAK/STAT pathway. Am J Transl Res. (2018) 10:2737-46.

88. Boonstra A, Barrat FJ, Crain C, Heath VL, Savelkoul HF, O'Garra A. 1alpha,25-Dihydroxyvitamin $\mathrm{d} 3$ has a direct effect on naive CD4(+) $\mathrm{T}$ cells to enhance the development of Th2 cells. J Immunol. (2001) 167:4974-80. doi: 10.4049/jimmunol.167.9.4974

89. Hayes CE, Nashold FE, Spach KM, Pedersen LB. The immunological functions of the vitamin D endocrine system. Cell Mol Biol. (2003) 49:277300.

90. Caballero-Velazquez T, Montero I, Sanchez-Guijo F, Parody R, Saldana R, Valcarcel D, et al. Immunomodulatory effect of vitamin D after allogeneic stem cell transplantation: results of a prospective multicenter clinical trial. Clin Cancer Res. (2016) 22:5673-81. doi: 10.1158/1078-0432.CCR-16-0238

91. Schardey J, Globig AM, Janssen C, Hofmann M, Manegold P, Thimme $\mathrm{R}$, et al. Vitamin $\mathrm{D}$ inhibits pro-inflammatory $\mathrm{T}$ cell function in patients with inflammatory bowel disease. J Crohns Colitis. (2019). doi: 10.1093/ecco-jcc/jjz090. [Epub ahead of print].

92. Iho S, Takahashi T, Kura F, Sugiyama H, Hoshino T. The effect of 1,25dihydroxyvitamin D3 on in vitro immunoglobulin production in human B cells. J Immunol. (1986) 136:4427-31.

93. Chen S, Sims GP, Chen XX, Gu YY, Chen S, Lipsky PE. Modulatory effects of 1,25-dihydroxyvitamin D3 on human B cell differentiation. J Immunol. (2007) 179:1634-47. doi: 10.4049/jimmunol.179.3.1634

94. Radujkovic A, Kordelas L, Krzykalla J, Beelen DW, Benner A, Lehners N, et al. Pretransplant vitamin D deficiency is associated with higher relapse rates in patients allografted for myeloid malignancies. J Clin Oncol. (2017) 35:3143-52. doi: 10.1200/JCO.2017.73.0085

95. Hansson ME, Norlin AC, Omazic B, Wikstrom AC, Bergman P, Winiarski $\mathrm{J}$, et al. Vitamin d levels affect outcome in pediatric hematopoietic stem cell transplantation. Biol Blood Marrow Transplant. (2014) 20:1537-43. doi: 10.1016/j.bbmt.2014.05.030

96. Lee HJ, Muindi JR, Tan W, Hu Q, Wang D, Liu S, et al. Low 25(OH) vitamin D3 levels are associated with adverse outcome in newly diagnosed, intensively treated adult acute myeloid leukemia. Cancer. (2014) 120:521-9. doi: $10.1002 / \mathrm{cncr} .28368$

97. Wallace G, Jodele S, Myers KC, Dandoy CE, El-Bietar J, Nelson A, et al. Vitamin D deficiency in pediatric hematopoietic stem cell transplantation patients despite both standard and aggressive supplementation. Biol Blood Marrow Transplant. (2016) 22:1271-4. doi: 10.1016/j.bbmt.2016.03.026 
98. Bertino JR. Landmark study: the relation of solar radiation to cancer mortality in North America. Cancer Res. (2016) 76:185. doi: 10.1158/0008-5472.CAN-15-3169

99. Colston K, Colston MJ, Feldman D. 1,25-dihydroxyvitamin D3 and malignant melanoma: the presence of receptors and inhibition of cell growth in culture. Endocrinology. (1981) 108:1083-6. doi: 10.1210/endo-108-3-1083

100. Giammanco M, Di Majo D, La Guardia M, Aiello S, Crescimannno M, Flandina C, et al. Vitamin D in cancer chemoprevention. Pharm Biol. (2015) 53:1399-434. doi: 10.3109/13880209.2014.988274

101. Garland CF, Gorham ED, Mohr SB, Garland FC. Vitamin D for cancer prevention: global perspective. Ann Epidemiol. (2009) 19:468-83. doi: 10.1016/j.annepidem.2009.03.021

102. Kasiappan R, Shen Z, Tse AK, Jinwal U, Tang J, Lungchukiet P, et al. 1,25-Dihydroxyvitamin D3 suppresses telomerase expression and human cancer growth through microRNA-498. J Biol Chem. (2012) 287:41297-309. doi: 10.1074/jbc.M112.407189

103. Frampton RJ, Omond SA, Eisman JA. Inhibition of human cancer cell growth by 1,25-dihydroxyvitamin D3 metabolites. Cancer Res. (1983) 43:4443-7.

104. Honma Y, Hozumi M, Abe E, Konno K, Fukushima M, Hata S, et al. 1 alpha,25-Dihydroxyvitamin D3 and 1 alpha-hydroxyvitamin D3 prolong survival time of mice inoculated with myeloid leukemia cells. Proc Natl Acad Sci USA. (1983) 80:201-4. doi: 10.1073/pnas.80.1.201

105. Bernardi RJ, Johnson CS, Modzelewski RA, Trump DL. Antiproliferative effects of 1alpha,25-dihydroxyvitamin $\mathrm{D}(3)$ and vitamin $\mathrm{D}$ analogs on tumor-derived endothelial cells. Endocrinology. (2002) 143:2508-14. doi: 10.1210/endo.143.7.8887

106. Getzenberg RH, Light BW, Lapco PE, Konety BR, Nangia AK, Acierno JS, et al. Vitamin D inhibition of prostate adenocarcinoma growth and metastasis in the Dunning rat prostate model system. Urology. (1997) 50:999-1006. doi: 10.1016/S0090-4295(97)00408-1

107. Colston KW, Chander SK, Mackay AG, Coombes RC. Effects of synthetic vitamin $\mathrm{D}$ analogues on breast cancer cell proliferation in vivo and in vitro. Biochem Pharmacol. (1992) 44:693-702. doi: 10.1016/0006-2952(92)90405-8

108. Ooi LL, Zhou H, Kalak R, Zheng Y, Conigrave AD, Seibel MJ, et al. Vitamin D deficiency promotes human breast cancer growth in a murine model of bone metastasis. Cancer Res. (2010) 70:1835-44. doi: 10.1158/0008-5472.CAN-09-3194

109. Higashimoto Y, Ohata M, Nishio K, Iwamoto Y, Fujimoto H, Uetani K, et al. 1 alpha, 25-dihydroxyvitamin D3 and all-trans-retinoic acid inhibit the growth of a lung cancer cell line. Anticancer Res. (1996) 16:2653-9.

110. Kornfehl J, Formanek M, Temmel A, Knerer B, Willheim M. Antiproliferative effects of the biologically active metabolite of vitamin D3 $(1,25[\mathrm{OH}] 2 \mathrm{D} 3)$ on head and neck squamous cell carcinoma cell lines. Eur Arch Otorhinolaryngol. (1996) 253:341-4. doi: 10.1007/BF00178289

111. Gharbaran R, Zhang B, Valerio L, Onwumere O, Wong M, Mighty J, et al. Effects of vitamin D3 and its chemical analogs on the growth of Hodgkin's lymphoma, in vitro. BMC Res Notes. (2019) 12:216. doi: 10.1186/s13104-019-4241-0

112. Shanafelt TD, Drake MT, Maurer MJ, Allmer C, Rabe KG, Slager SL, et al. Vitamin D insufficiency and prognosis in chronic lymphocytic leukemia. Blood. (2011) 117:1492-8. doi: 10.1182/blood-2010-07-295683

113. Ding EL, Mehta S, Fawzi WW, Giovannucci EL. Interaction of estrogen therapy with calcium and vitamin D supplementation on colorectal cancer risk: reanalysis of Women's Health Initiative randomized trial. Int J Cancer. (2008) 122:1690-4. doi: 10.1002/ijc.23311

114. Antunac Golubic Z, Barsic I, Librenjak N, Plestina S. Vitamin D supplementation and survival in metastatic colorectal cancer. Nutr Cancer. (2018) 70:413-7. doi: 10.1080/01635581.2018.1445766

115. Brandstedt J, Almquist M, Manjer J, Malm J. Vitamin D, PTH, and calcium and the risk of prostate cancer: a prospective nested case-control study. Cancer Causes Control. (2012) 23:1377-85. doi: 10.1007/s10552-0129948-3

116. Chlebowski RT, Johnson KC, Kooperberg C, Pettinger M, WactawskiWende J, Rohan T, et al. Calcium plus vitamin D supplementation and the risk of breast cancer. J Natl Cancer Inst. (2008) 100:1581-91. doi: $10.1093 /$ jnci/djn360

117. Chen PT, Hsieh CC, Wu CT, Yen TC, Lin PY, Chen WC, et al. 1alpha,25dihydroxyvitamin D3 inhibits esophageal squamous cell carcinoma progression by reducing IL6 signaling. Mol Cancer Ther. (2015) 14:1365-75. doi: 10.1158/1535-7163.MCT-14-0952

118. Barry EL, Peacock JL, Rees JR, Bostick RM, Robertson DJ, Bresalier RS, et al. Vitamin D receptor genotype, vitamin D3 supplementation, and risk of colorectal adenomas: a randomized clinical trial. JAMA Oncol. (2017) 3:628-35. doi: 10.1001/jamaoncol.2016.5917

119. Huerta S, Irwin RW, Heber D, Go VL, Koeffler HP, Uskokovic MR, et al lalpha,25-(OH)(2)-D(3) and its synthetic analogue decrease tumor load in the Apc(min) Mouse. Cancer Res. (2002) 62:741-6.

120. Otoshi $\mathrm{T}$, Iwata $\mathrm{H}$, Kitano $\mathrm{M}$, Nishizawa $\mathrm{Y}$, Morii $\mathrm{H}$, Yano $\mathrm{Y}$, et al. Inhibition of intestinal tumor development in rat multi-organ carcinogenesis and aberrant crypt foci in rat colon carcinogenesis by 22-oxa-calcitriol, a synthetic analogue of 1 alpha, 25-dihydroxyvitamin D3. Carcinogenesis. (1995) 16:2091-7. doi: 10.1093/carcin/16.9.2091

121. Chiang KC, Yeh CN, Hsu JT, Chen LW, Kuo SF, Sun CC, et al. MART10 , a novel vitamin D analog, inhibits head and neck squamous carcinoma cells growth through cell cycle arrest at G0/G1 with upregulation of p21 and p27 and downregulation of telomerase. J Steroid Biochem Mol Biol. (2013) 138:427-34. doi: 10.1016/j.jsbmb.2013.09.002

122. Zinser GM, Suckow M, Welsh J. Vitamin D receptor (VDR) ablation alters carcinogen-induced tumorigenesis in mammary gland, epidermis and lymphoid tissues. J Steroid Biochem Mol Biol. (2005) 97:153-64. doi: 10.1016/j.jsbmb.2005.06.024

123. Zhou JY, Norman AW, Chen DL, Sun GW, Uskokovic M, Koeffler HP. 1,25-Dihydroxy-16-ene-23-yne-vitamin D3 prolongs survival time of leukemic mice. Proc Natl Acad Sci USA. (1990) 87:3929-32. doi: 10.1073/pnas.87.10.3929

124. Banach-Petrosky W, Ouyang X, Gao H, Nader K, Ji Y, Suh N, et al. Vitamin D inhibits the formation of prostatic intraepithelial neoplasia in Nkx3.1;Pten mutant mice. Clin Cancer Res. (2006) 12:5895-901. doi: 10.1158/1078-0432.CCR-06-1039

125. Whitlatch LW, Young MV, Schwartz GG, Flanagan JN, Burnstein KL, Lokeshwar BL, et al. 25-Hydroxyvitamin D-1alpha-hydroxylase activity is diminished in human prostate cancer cells and is enhanced by gene transfer. J Steroid Biochem Mol Biol. (2002) 81:135-40. doi: 10.1016/S0960-0760(02)00053-5

126. Hsu JY, Feldman D, McNeal JE, Peehl DM. Reduced 1alpha-hydroxylase activity in human prostate cancer cells correlates with decreased susceptibility to 25-hydroxyvitamin D3-induced growth inhibition. Cancer Res. (2001) 61:2852-6.

127. Feldman D, Krishnan AV, Swami S, Giovannucci E, Feldman BJ. The role of vitamin D in reducing cancer risk and progression. Nat Rev Cancer. (2014) 14:342-57. doi: 10.1038/nrc3691

128. Hoyer-Hansen M, Bastholm L, Mathiasen IS, Elling F, Jaattela M. Vitamin D analog EB1089 triggers dramatic lysosomal changes and Beclin 1mediated autophagic cell death. Cell Death Differ. (2005) 12:1297-309. doi: 10.1038/sj.cdd.4401651

129. Fleet JC, DeSmet M, Johnson R, Li Y. Vitamin D and cancer: a review of molecular mechanisms. Biochem J. (2012) 441:61-76. doi: 10.1042/BJ20110744

130. Jiang F, Bao J, Li P, Nicosia SV, Bai W. Induction of ovarian cancer cell apoptosis by 1,25-dihydroxyvitamin D3 through the down-regulation of telomerase. J Biol Chem. (2004) 279:53213-21. doi: 10.1074/jbc.M410395200

131. Wang QM, Jones JB, Studzinski GP. Cyclin-dependent kinase inhibitor p27 as a mediator of the G1-S phase block induced by 1,25-dihydroxyvitamin D3 in HL60 cells. Cancer Res. (1996) 56:264-7.

132. Pendas-Franco N, Garcia JM, Pena C, Valle N, Palmer HG, Heinaniemi $\mathrm{M}$, et al. DICKKOPF-4 is induced by TCF/beta-catenin and upregulated in human colon cancer, promotes tumour cell invasion and angiogenesis and is repressed by 1alpha,25-dihydroxyvitamin D3. Oncogene. (2008) 27:4467-77. doi: 10.1038/onc.2008.88

133. Ben-Shoshan M, Amir S, Dang DT, Dang LH, Weisman Y, Mabjeesh NJ. 1alpha,25-dihydroxyvitamin D3 (Calcitriol) inhibits hypoxia-inducible factor-1/vascular endothelial growth factor pathway in human cancer cells. Mol Cancer Ther. (2007) 6:1433-9. doi: 10.1158/1535-7163.MCT-06-0677

134. Iseki K, Tatsuta $M$, Uehara $H$, Iishi $H$, Yano $H$, Sakai $N$, et al. Inhibition of angiogenesis as a mechanism for inhibition by 1alpha-hydroxyvitamin D3 and 1,25-dihydroxyvitamin D3 of colon carcinogenesis induced by 
azoxymethane in Wistar rats. Int J Cancer. (1999) 81:730-3. doi: 10.1002/ (SICI)1097-0215(19990531)81:5<730::AID-IJC11>3.3.CO;2-H

135. Tavera-Mendoza LE, Westerling T, Libby E, Marusyk A, Cato L, Cassani $\mathrm{R}$, et al. Vitamin $\mathrm{D}$ receptor regulates autophagy in the normal mammary gland and in luminal breast cancer cells. Proc Natl Acad Sci USA. (2017) 114:E2186-94. doi: 10.1073/pnas.1615015114

136. Bruns H, Buttner M, Fabri M, Mougiakakos D, Bittenbring JT, Hoffmann $\mathrm{MH}$, et al. Vitamin D-dependent induction of cathelicidin in human macrophages results in cytotoxicity against high-grade B cell lymphoma. Sci Transl Med. (2015) 7:282ra47. doi: 10.1126/scitranslmed.aaa3230

137. Busch L, Mougiakakos D, Buttner-Herold M, Muller MJ, Volmer DA, Bach $\mathrm{C}$, et al. Lenalidomide enhances MOR202-dependent macrophage-mediated effector functions via the vitamin D pathway. Leukemia. (2018) 32:2445-58. doi: 10.1038/s41375-018-0114-0

138. Flamann C, Busch L, Mackensen A, Bruns H. Combination of lenalidomide and vitamin D enhances MOR202-mediated cytotoxicity of macrophages: it takes three to tango. Oncotarget. (2019) 10:10-2. doi: 10.18632/oncotarget.26531

139. Bruns H, Bottcher M, Qorraj M, Fabri M, Jitschin S, Dindorf J, et al. CLLcell-mediated MDSC induction by exosomal miR-155 transfer is disrupted by vitamin Leukemia D. (2017) 31:985-8. doi: 10.1038/leu.2016.378

140. Balkwill F, Mantovani A. Inflammation and cancer: back to Virchow? Lancet. (2001) 357:539-45. doi: 10.1016/S0140-6736(00) 04046-0

141. Menkin V. Role of inflammation in carcinogenesis. Br Med J. (1960) 1:158594. doi: 10.1136/bmj.1.5186.1585

142. Eaden JA, Abrams KR, Mayberry JF. The risk of colorectal cancer in ulcerative colitis: a meta-analysis. Gut. (2001) 48:526-35. doi: 10.1136/gut.48.4.526

143. Krishnan AV, Feldman D. Molecular pathways mediating the antiinflammatory effects of calcitriol: implications for prostate cancer chemoprevention and treatment. Endocr Relat Cancer. (2010) 17:R19-38. doi: 10.1677/ERC-09-0139

144. Nonn L, Peng L, Feldman D, Peehl DM. Inhibition of p38 by vitamin D reduces interleukin-6 production in normal prostate cells via mitogen-activated protein kinase phosphatase 5: implications for prostate cancer prevention by vitamin D. Cancer Res. (2006) 66:4516-24. doi: 10.1158/0008-5472.CAN-05-3796

145. Wallace G, Jodele S, Myers KC, Dandoy CE, El-Bietar J, Nelson A, et al. Single ultra-high-dose cholecalciferol to prevent vitamin D deficiency in pediatric hematopoietic stem cell transplantation. Biol Blood Marrow Transplant. (2018) 24:1856-60. doi: 10.1016/j.bbmt.2018.05.019

146. Leyssens C, Verlinden L, Verstuyf A. The future of vitamin D analogs. Front Physiol. (2014) 5:122. doi: 10.3389/fphys.2014.00122

147. Alagbala AA, Johnson CS, Trump DL, Posner GH, Foster BA. Antitumor effects of two less-calcemic vitamin D analogs (Paricalcitol and QW1624F2-2) in squamous cell carcinoma cells. Oncology. (2006) 70:483-92. doi: $10.1159 / 000098813$

148. von Essen MR, Kongsbak M, Schjerling P, Olgaard K, Odum N, Geisler C. Vitamin D controls T cell antigen receptor signaling and activation of human T cells. Nat Immunol. (2010) 11:344-9. doi: 10.1038/ni.1851

149. Bendix-Struve M, Bartels LE, Agnholt J, Dige A, Jorgensen SP, Dahlerup JF. Vitamin D3 treatment of Crohn's disease patients increases stimulated T cell IL-6 production and proliferation. Aliment Pharmacol Ther. (2010) 32:1364-72. doi: 10.1111/j.1365-2036.2010.04463.x

150. Bruce D, Cantorna MT. Intrinsic requirement for the vitamin D receptor in the development of CD8alphaalpha-expressing T cells. J Immunol. (2011) 186:2819-25. doi: 10.4049/jimmunol.1003444

Conflict of Interest: The authors declare that the research was conducted in the absence of any commercial or financial relationships that could be construed as a potential conflict of interest.

Copyright (c) 2019 Flamann, Peter, Kreutz and Bruns. This is an open-access article distributed under the terms of the Creative Commons Attribution License (CC BY). The use, distribution or reproduction in other forums is permitted, provided the original author(s) and the copyright owner(s) are credited and that the original publication in this journal is cited, in accordance with accepted academic practice. No use, distribution or reproduction is permitted which does not comply with these terms. 